\title{
A RECONSTRUCTION OF THE PLEISTOCENE MAXIMUM IN THE ZIJOVO RANGE (PROKLETIJE MOUNTAINS, MONTENEGRO)
}

Aleksandar S. Petrović

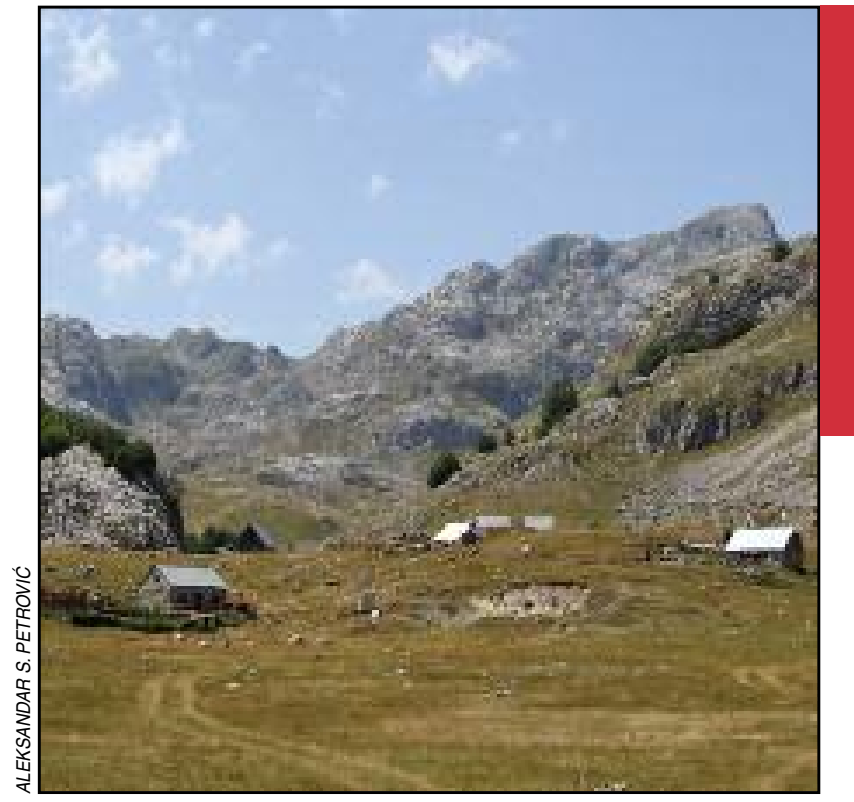

The Žijovo Range, shepherds' huts in the Rikavac Pasture. 


\section{A Reconstruction of the Pleistocene Glacial Maximum in the Žijovo Range (Prokletije Mountains, Montenegro)}

DOI: http://dx.doi.org/10.3986/AGS54202

UDC: 911.2:551.324(497.16)"628.62"

COBISS: 1.01

ABSTRACT: The Žijovo Range belongs to the Prokletije Mountains of Montenegro and is located in the extreme southeast, on the border with Albania. Glacial processes were intensively active in this range during the Pleistocene. This is indicated by erosive and accumulative glacial features of relief that have been preserved due to the favorable geologic structure. The glacial maximum in the Žijovo Range is characterized by a unique glacier on the entire area of the range. Preglacial relief prevented the formation of a typical icecap glacier. Due to drainage of the central glacial mass in the direction of the preglacial valleys, there was a transection glacier in the central, northern, and northwestern parts, and an icefield glacier in the eastern and southeastern parts of the Žijovo Range. These glaciers covered an area of $180 \mathrm{~km}$ during the glacial maximum.

KEY WORDS: geography, glaciations, glacier reconstruction, Pleistocene, Žijovo Range, Prokletije Mountains, Montenegro

The article was submitted for publication on January 26th, 2013.

ADDRESS:

Aleksandar S. Petrović, M. Sc.

University of Belgrade, Faculty of Geography

Studentski trg 3/III, 11000 Belgrade, Serbia

E-mail: apetrovic@gef.bg.ac.rs 


\section{Introduction}

Studies of the Pleistocene glaciation of the mountains of Montenegro have intensified in the last two decades, in parallel with studies of current glaciers in the region. However, the Dinaric and Prokletije Mountains of Montenegro were at the focus of researchers' attention even at the end of the nineteenth century and in early twentieth century, at the very beginning of the first studies of Pleistocene glaciation (Renji 1901; Hasert 1901; Martel 1908; Cvijić 1903, 1913). The results of these studies laid the methodological foundation for future reconstruction of the Pleistocene glaciation.

Past studies detected glacial traces on many mountains in Montenegro's Dinaric and Prokletije group, and systematic research was carried out on some of them. Some mountains, including the Žijovo Range, attracted the attention of researchers almost a century later.

This paper has three principal aims: 1) to present geomorphological evidence of extent of the glacial maximum in the Žijovo Range, 2) to establish the type and volume of glacial maximum, and 3) to determine the equilibrium line altitude (ELA) during the glacial maximum.

\section{Study area}

The Žijovo Range belongs to the Prokletije Mountains of Montenegro and is located in the extreme southeast, on the border with Albania (Figure 1). It lies in the zone in which the Dinaric Mountains (oriented northwest-southeast) meet the »Albanian« mountains (oriented almost along the meridian; Cvijić 1899). The Žijovo Range is a group name for a several peaks that rise above the Kuči Plateau. One of these is also named Mount Zijovo. Therefore, this range is also known as the Kuči Range.

The summits that rise above the Kuči Plateau reach elevations between 1,800 and 2,200 m. Mount Surdup is the highest peak, at 2,184 m. In the central part of the range all summits are above 2,000 m. The Kuči Plateau is divided into three smaller parts: the Kržanja-Orahovo Plateau, the Kučka Krajina Plateau, and Korita Kučka Plateau.

The Žijovo Range is a watershed between two sea drainage basins and four river drainage basins. The major part of its area belongs to the Adriatic Drainage Basin (the Cijevna and Little Rijeka [Mala Rijeka] rivers) and its northern part belongs to the Black Sea Drainage Basin (the Tara and Lim rivers).

The study area is almost entirely composed of carbonate rocks from the Mesozoic Era. Dolomites and dolomite limestone are predominant, but there are also limestone and limestone breccia (Djokić et al. 1968). Sedimentary rocks shaped by glacial and slope process are found on the mountain slopes, at the bottom of cirques, and in larger dolines, as well as on the Kuči Plateau.

\section{Research methodology}

Field surveys and field mapping in the Žijovo Range were carried out between 2003 and 2012. The main goal was to identify and delineate glacial landforms and sediments and to genetically interpret them. Paleo-glacial features such as cirques, glacial troughs, roches moutonnées, glacial shoulders, nunataks, glacial erratics, and glacial sediments were entered into the field map. Remote-sensing techniques were used to detect large features, for which aerial photographs were used (Vojnogeografski institut 1982).

The data obtained from the field and remote-sensing methods were entered into a thematic geomorphological map, the base of which is a 1:25,000 oro-hydrographic map. Analyzing the geomorphological map that was constructed, data were obtained on landform morphology, relief genesis, and the spatial arrangement of relief elements and their interrelationships.

The glacial sediments detected in the Žijovo Range were processed with basic field techniques commonly used in the description and analysis of glaciogenic sediments, such as sediment texture, particle morphology, bedding, and so on (Hubbard and Glasser 2005). For particle-size classification, a diagram assembled by Blott and Pye (2001) was used. On the basis of lithostratigraphic and morphostratigraphic characteristics, glacial sediments were divided into lower lithologic units, following the principles of the formal stratigraphic approach developed for Quaternary glacial records in mountain regions (Hughes et al. 2005). The lithostratigraphic hierarchical terms used in this article correspond to a formal stratigraphic approach. 
The glacial maximum in the Žijovo Range is defined by the lowermost limit of glacial deposits. Flint's glacierization model of »windward growth « (1971) was used to explain glaciation type and the size of glaciation in the Žijovo Range. The main characteristic of this model emphasizes the role of precipitation in the mountain area in glacier growth. This model explains the high mountain glaciation formed in the direction of the main air mass circulation.

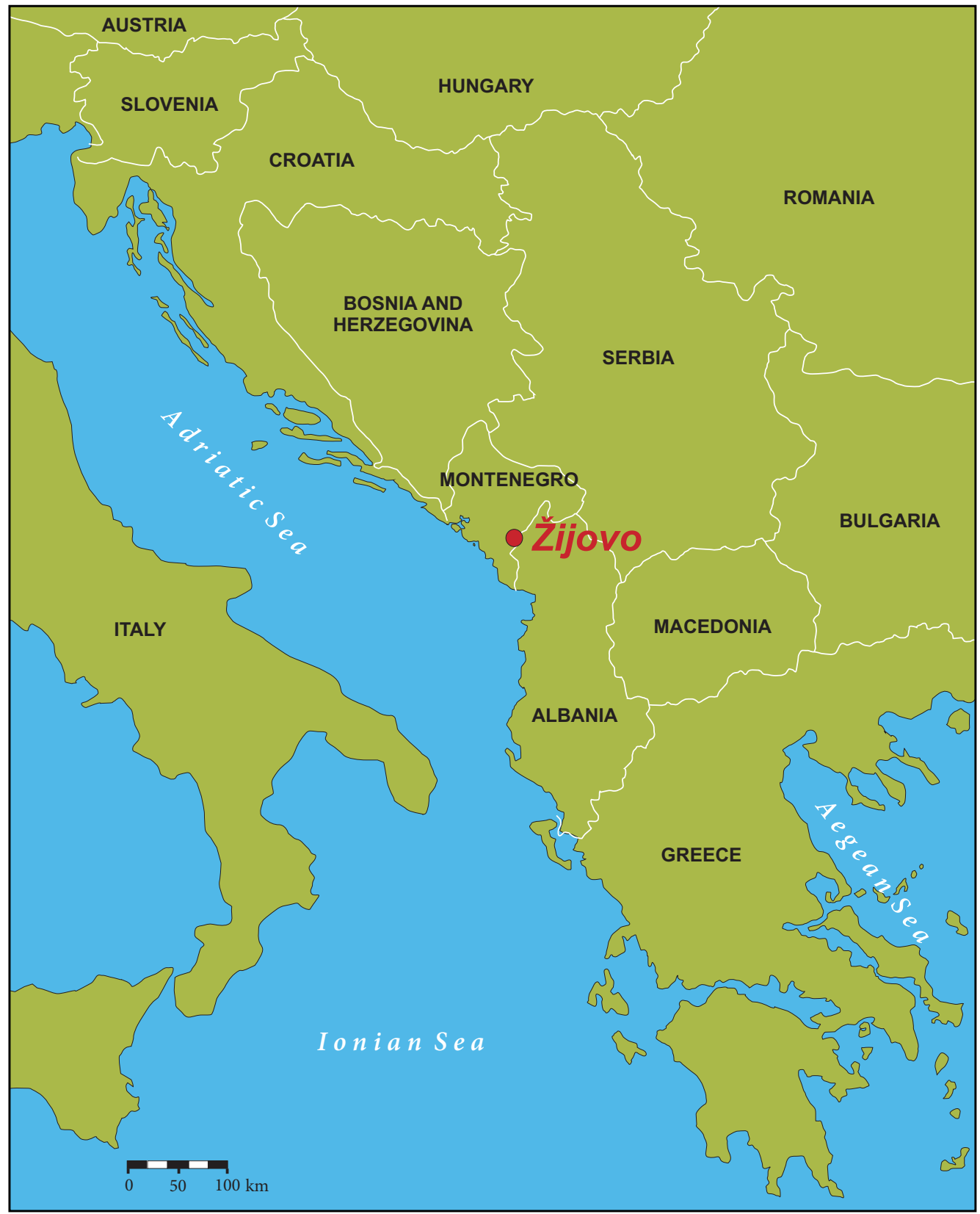

Figure 1: Geographic position of the study area. 
The morphological characteristics of broader surroundings of the Žijovo Range, canyon valleys, and wide plateau modified the scope of glaciation and therefore the length of the glacier. For this reason, applying the median altitude method (Porter 2001) to reconstruct the equilibrium line altitude (ELA), which lies at the halfway point between the head of a glacier and its terminus, does not yield reliable results for all glaciers. Due to the most favorable morphological characteristics for undisturbed movement of glaciers through the preglacial Veruša and Brskut valleys, a combination of different methods for defining the ELA was applied to the Pleistocene Širokar and Bukumir glaciers. Comparing the results for the ELA of adjacent mountains (Milivojević 2004; Milivojević et al. 2008), the best result was obtained using the THAR (terminus-to-head altitude ratio) method when the value 0.4 was used for THAR in the equation (Figure 2), as suggested by Meierding (1982).

$$
\mathrm{ELA}=\mathrm{A}_{\mathrm{t}}+\operatorname{THAR}\left(\mathrm{A}_{\mathrm{h}}-\mathrm{A}_{\mathrm{t}}\right) \text {, }
$$

where $A_{t}$ is altitude of the terminus of a glacier, $A_{h}$ is altitude of the head of a glacier and THAR $=0.4$.

\section{Previous studies of glaciation in the Žijovo Range}

At the beginning of research on the Pleistocene glaciation in the Balkan Mountains, the Kuči Range represented a major organizational challenge, considering the political circumstances and situation in the field around 1900. Nonetheless, several leading researchers carried out studies as part of larger expeditions on the Kuči Range. Their research sought to confirm the existence of morphological traces of the Pleistocene glaciation.

The first confirmation of Pleistocene glaciers was provided by Hasert (1901), who detected a ground moraine at Lake Bukumir, and so he assumed that the glacier there had descended to $1,450 \mathrm{~m}$. That same year, Renji (1901) found traces of glaciation around Lake Rikavac, on Mount Širokar, and in the Veruša Valley. The existence of moraine material on the Kuči Plateau, and also fluvioglacial material in the basins of the Cijevna and Little Rijeka rivers, were first detected by Martel (1908). He also mentioned west-oriented cirques in the Žijovo Range.

Jovan Cvijić paid special attention to reconstruction of glaciation in the Žijovo Range. Considering glaciation in the mountains of the Balkan Peninsula, he assumed that the elevation of the snow-line on Mount Širokar was between 1,600 and 1,700 m (Cvijić 1903). He talked about the Žijovo Range and the Kuči Plateau especially in his paper on glaciation of the Prokletije Mountains (Cvijić 1913), in which he also mentioned the "Kuči Glacier of karst type. "According to him, this glacier covered $115 \mathrm{~km}^{2}$ and was not a unique ice cover; there were also several local glaciers (the Šrokar Glacier, Rikavac Glacier, Maglić Glacier, and Bukumir Cirque on the southern side of Mount Surdup in the Žijovo Range, on Mount Kostić, and on Orahovo Hill). These glaciers moved towards the normal valleys of adjacent rivers (Cvijić 1913).

In recent years, the Pleistocene glaciation of the Žijovo Range has again attracted researchers' attention (Petrović 2007; 2009). The objective of this study was to reconstruct the Pleistocene glaciation in the Žijovo Range and on the Kuči Plateau. The influence of the Pleistocene glaciation on the current relief of the range was also studied, especially on the morphological diversity of uvalas in it (Djurović et al. 2010).

\section{Pleistocene glacial relief features in the Žijovo Range}

The traces that glaciers left in the Žijovo Range are well preserved. This is due to the geological structure of the range, in which carbonate rocks predominate. Because karst processes were dominant in the Holocene in this range (Djurović et al. 2010), there was no possibility for the development of surface watercourses that would destroy previously formed macro- and meso-relief features through erosion.

Research on the glaciation of the Pindus Mountains in northwestern Greece has concluded that glacial processes develop better on a limestone base than on other rocks, especially magma, and that this also preserves their traces well (Hughes et al. 2007). The development of glaciation on a karst surface also creates specific relief features known as glaciokarst (Cvijić 1913; Djurović 1996; Stepišnik et al. 2009; Stepišnik \& Žebre 2011), which can also be found in the Žijovo Range. For all of these reasons, it is possible to clearly identify erosive and accumulative relief features of the Pleistocene glacial process in the Žijovo 
Range (Petrović 2009). Considering the large number of features, this article presents only the most important features for reconstructing the glacial maximum.

\subsection{Cirques and glacial troughs}

Cirques are predominant large features of the glacial process in the Žijovo Range (Figure 5). Based on their characteristics, they can be divided into three groups: cirques in the central part of the range, in the western edge of the range, and in the eastern part of the range.

Based on their appearance, the cirques in the central part of the range correspond to features created by glaciers of the valley type. In their size and morphology, the Širokar, Surdup, and Gladišta cirques especially stand out (Figure 5). Typical glacial troughs spread below these cirques, whereby they differ from the majority of other cirques in the range.

The Surdup Cirque is the most distinct representative of this group of cirques (Figure 3). It is located on the northern side of Mount Surdup, the highest summit. Steep ridges rise over $200 \mathrm{~m}$ above its bottom, located at $1,800 \mathrm{~m}$. The Surdup Cirque is $1,250 \mathrm{~m}$ wide and $550 \mathrm{~m}$ long. It is exposed to the north, where there are two passages to the glacial trough. Between these passages rises Pašjak Nunatak (2,052 m), a typical nunatak. Glacial shoulders are visible on the sides of Pašjak Nunatak. Below the cirque, to the northwest, the Bukumir Glacial Trough is over $5 \mathrm{~km}$ long. The bottom of the glacial trough is covered with roches moutonnées and hollowed areas with lakes. The largest lake is Lake Bukumir (Figure 4-1).

The cirques on the western edge of the range were first identified by Martel (1908). They are distinctive because the Pleistocene glacier flowed directly from them over the western part of the Kuči Plateau (the Kržanja-Orahovo Plateau). This group of cirques also includes the Žijovo Cirque, Radan Cirque, Bokjen Cirque, and Šila Cirque. Based on the field survey and mapping, as well as aerial photograph analysis, a clear reconstruction was made of the former threshold that separated these cirques from the plateau. Today this threshold has been significantly altered by post-glacial processes.

The Žijovo Cirque is located west of Mount Žijovo. It has high ridges on three sides (Figure 4-2). The bottom lies at $1,750 \mathrm{~m}$. It is $1,000 \mathrm{~m}$ wide and it extends $1,500 \mathrm{~m}$ to the northwest. The Žijovo Cirque looks like a complex cirque (Benn \& Evans 1998), which is one of the distinctive characteristics of this group of cirques. On the sides of this large cirque there are several hanging cirques (at 1,970 m) created during younger phases of glaciation. The remains of the threshold that morphologically separates the Žijovo Cirque from the plateau are at $1,790 \mathrm{~m}$.

The cirques in the eastern part of the Žijovo Range are located in the northeastern and eastern part of the study area, between the Cijevna Canyon to the east, the Kuči Plateau to the south and southeast (the Korita Kučka and Kučka Krajina plateaus), and the Skrobotuša Valley to the north (Figure 5). The average elevation of this part of the mountain is over $1,700 \mathrm{~m}$. It is located between two sequences of mountain summits over $2,000 \mathrm{~m}$ and it is slightly centrally arched (Figure 4-3). Considering that the entire area was beneath a unique glacier for long time, cirques of specific types were created. They have a large area $\left(\right.$ over $\left.10 \mathrm{~km}^{2}\right)$ and volume. They do not have high ridges on all sides, and so they seem less distinctive than

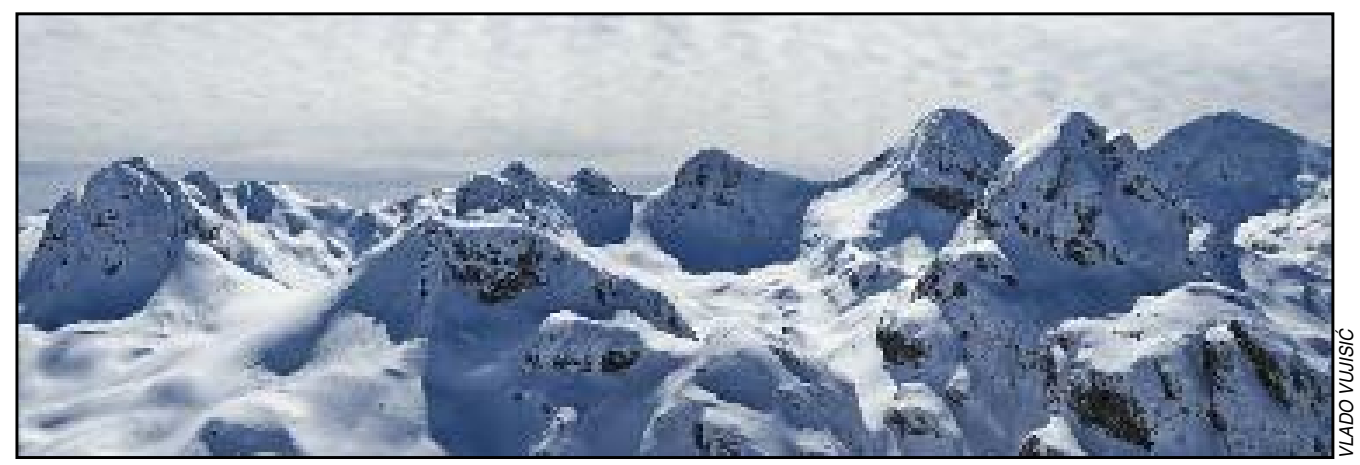

Figure 3: The current appearance of the Pleistocene Surdup Cirque. 


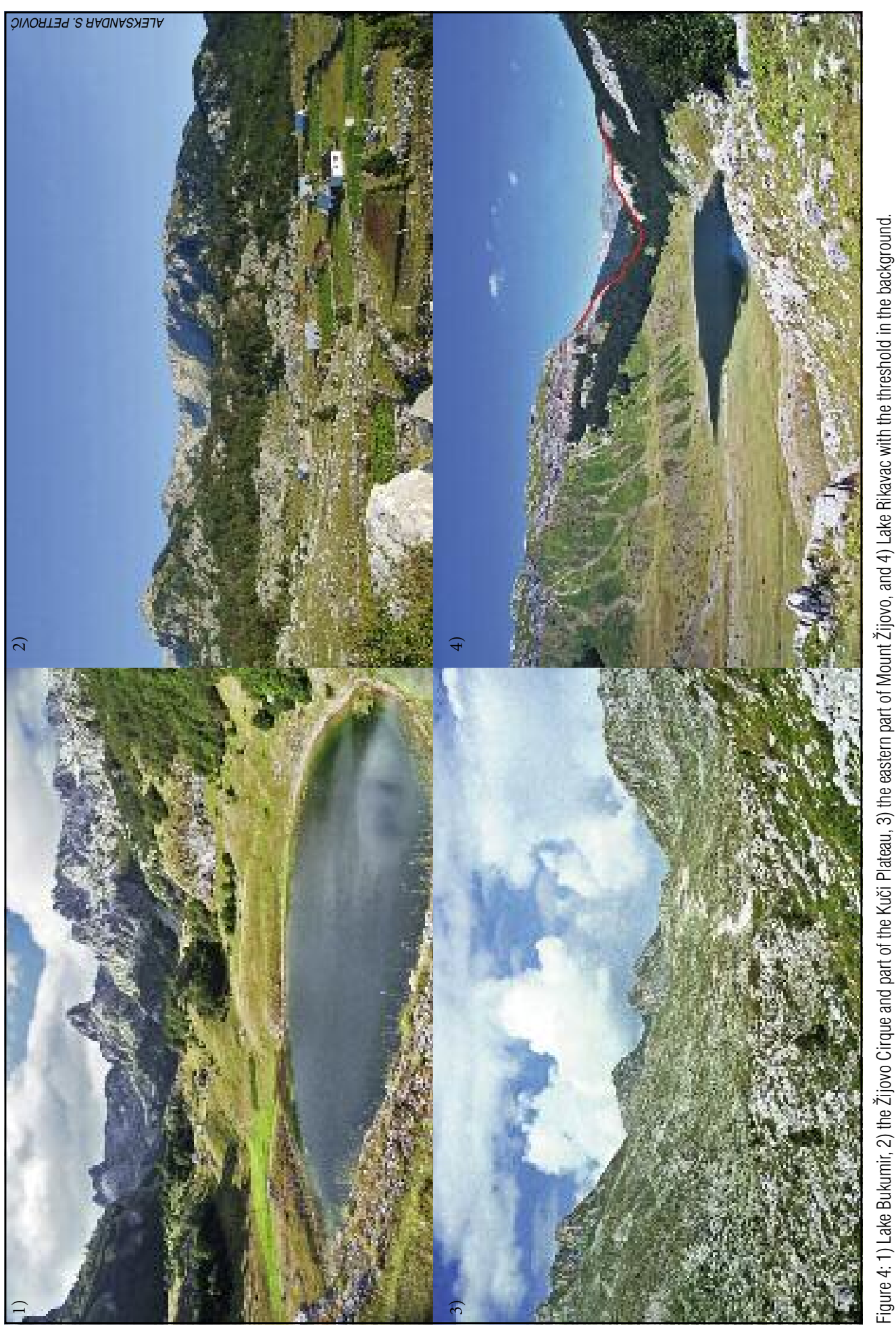




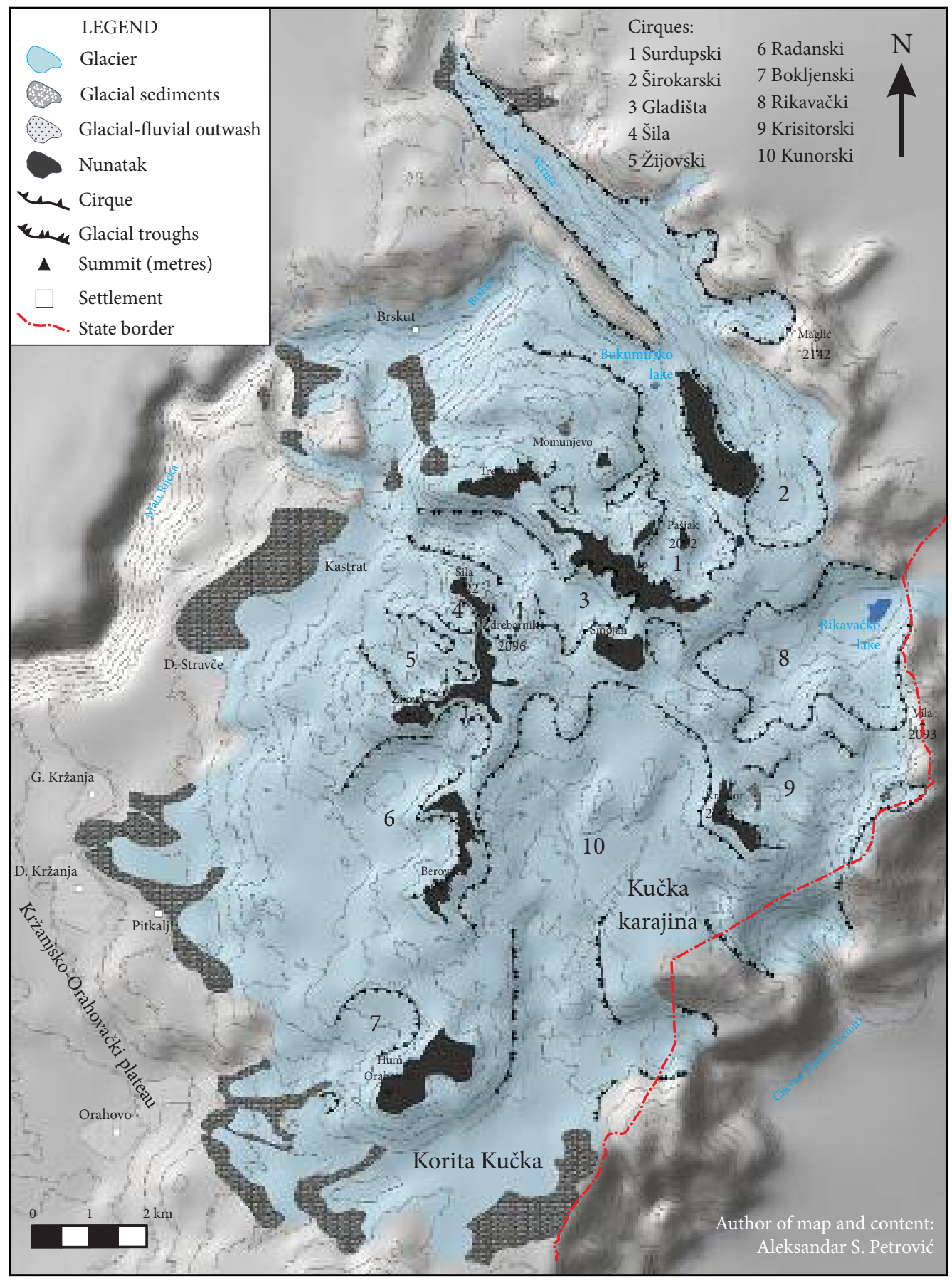

Figure 5: Glacial geomorphological map of the Žijovo Range; glacial maximum. 
the other cirques. It is clearly possible to single out three larger cirques: the Rikavac, Krisitor, and Kunora cirques. The Rikavac Cirque has a lowered threshold connected to the Skrobotuša Glacial Trough (in Albania).The Krisitor Cirque is open to the Cijevna Canyon (Albanian: Ljumi i Cemit). The Kunora Cirque opens wide to the Cijevna Canyon and the southern part of the Kuči Plateau (the Korita Kučka and Kučka Krajina plateaus).

The Rikavac Cirque was formed by alteration of the tectonically predisposed preglacial uvala in the meridian direction (Petrović 2009). It does not have the amphitheater-like appearance of a cirque, but its bottom is separated from the steeper sides of the mountains by part of the cirque with gentler slopes. On the higher edge of the cirque there are several hanging cirques from younger glaciation phases; therefore the Rikavac Cirque is also complex. At the bottom of the cirque $(1,300 \mathrm{~m})$, in front of the threshold that separates it from glacial troughs, is Lake Rikavac (Figure 4-4).

\subsection{Pleistocene glacial sediments}

The Pleistocene glacial sediments in the Žijovo Range and on the adjacent plateau belong to the Kuči group, which is composed of several formations: the Veruša Valley, the Bukumir Cirque, Plateau Momunjevo, Mount Žijovo, the Radan Cirque, the Bokjen Cirque, the Kunora Cirque, the Krisitor Cirque, and the Rikavac Cirque. For reconstructing the maximum volume of glaciation during the Pleistocene, the most important role is played by the glacial sediments of the Kržanja Member, and so they are presented below separately from the formation they belong to.

The Kržanja Member comprises glacial sediments located on the Kuči Plateau and in the Veruša and Brskut valleys (Figure 5). They are the lowest glacial sediments in the range and according to this criterion they are classified into the same group. However, their elevation differs significantly. The glacial deposits in the Brskut Valley are the lowest $(1,050-1,100 \mathrm{~m})$ because of the tectonic escarpment towards the valley. The terminal moraine in the Veruša Valley $(1,245 \mathrm{~m})$ was created by a glacier that freely moved along the preglacial river valley. Moraine crests on the western part of the Kuči Plateau (the Kržanja-Orahovo Plateau) vary in elevation $(1,150-1,520 \mathrm{~m})$ due to the different incline of the plateau, the vicinity of canyon valleys, and the size of the glacier accumulation area in the background.

The lowest glacial sediments accumulated in the Brskut Valley $(1,050-1,100 \mathrm{~m})$. The Brskut Valley is a tectonically predisposed relief feature created by the relative descent of boulders inside the Durmitor flysch geological unit (Djokić et al. 1968). The glaciers from the Žijovo Range fell from the steep escarpments of the Brskut Valley, $200 \mathrm{~m}$ high, accumulated glacial material, and melted there. Through orographic influence, the glacial sediments formed in this manner are located at rather low elevations compared to other Kržanja Member representatives. In the post-glacial period, the Brskut River carried this material further to the Little Rijeka and Morača rivers. The glacial and glacio-fluvial material in the Brskut Valley includes sand, mud, sandy clays with fragments of various sizes, pebbles, semi-rounded and partly rounded limestone, and dolomite boulders (Živaljević et al. 1967).

Moraine crests near the village of Donja Kržanja (1,150-1,200 m) are typical examples of glacial sediments of the Kržanja Member (Figure 6). Two lateral moraine crests are evident as well as a frontal moraine penetrated by a glacier stream, below which there is a glacio-fluvial outwash fan. South and north of them, there are two more parallel moraine crests above the villages of Pitkalj and Gornja Kržanja (Figure 5).

Similar image can be seen above village of Orahovo, where at the same elevation $(1,150 \mathrm{~m})$ there are two crests of terminal moraines and several lateral moraine crests in one sequence (Figure 5).

The terminal moraine in the Veruša Valley is well preserved. It transversally partitions the valley and it is open only at the place where the river penetrates the crest. The crest is at $1,240 \mathrm{~m}$; that is, $40 \mathrm{~m}$ above the bottom of the Veruša Valley. It is $450 \mathrm{~m}$ long (Cvijić 1913; Petrović 2007).

Considerable glacial sediments in the form of two interconnected terminal moraine crests are located above the village of Gornje Stravče and the shepherds' huts (katun) in the Kastrat Pasture. The terminal moraine in the southern part has a typical arch-like appearance and is at a lower elevation $(1,350 \mathrm{~m})$. Due to the vicinity of an escarpment towards the Brskut Valley over which part of the ice fell from the plateau, the northern part of the crest in the Kastrat Pasture is at a higher elevation $(1,540 \mathrm{~m})$. The crest is $3 \mathrm{~km}$ long and over $500 \mathrm{~m}$ wide (Figure 7). The sediments are poorly sorted and well distributed, consisting of large and medium-large sub-rounded and rounded limestone and dolomite boulders, between which there is sub-angular and sub-rounded gravel, sand, and clay. 

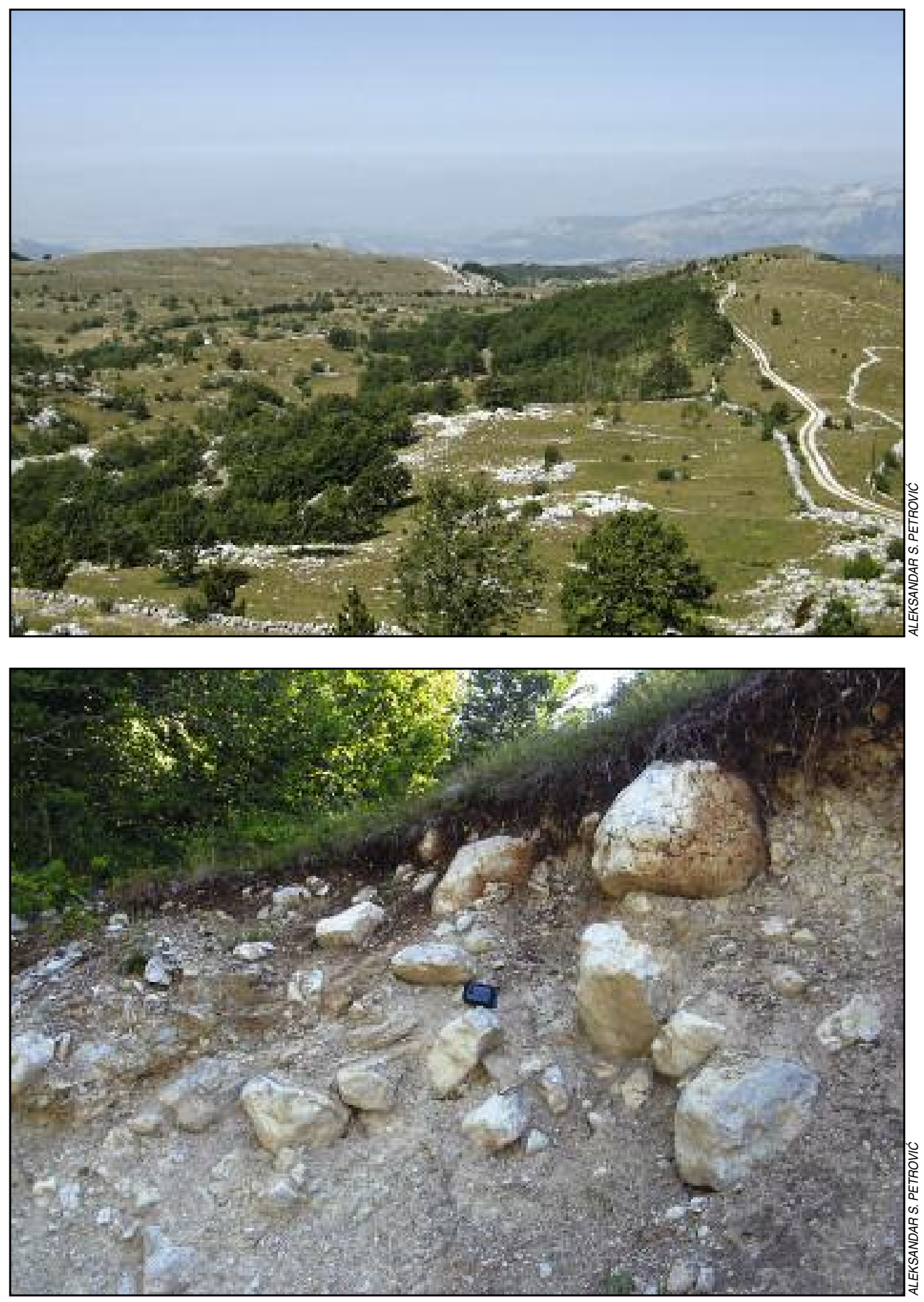

Figure 6: Moraine crests near Donja Kržanja and the profile through terminal moraine at Donja Kržanja. 

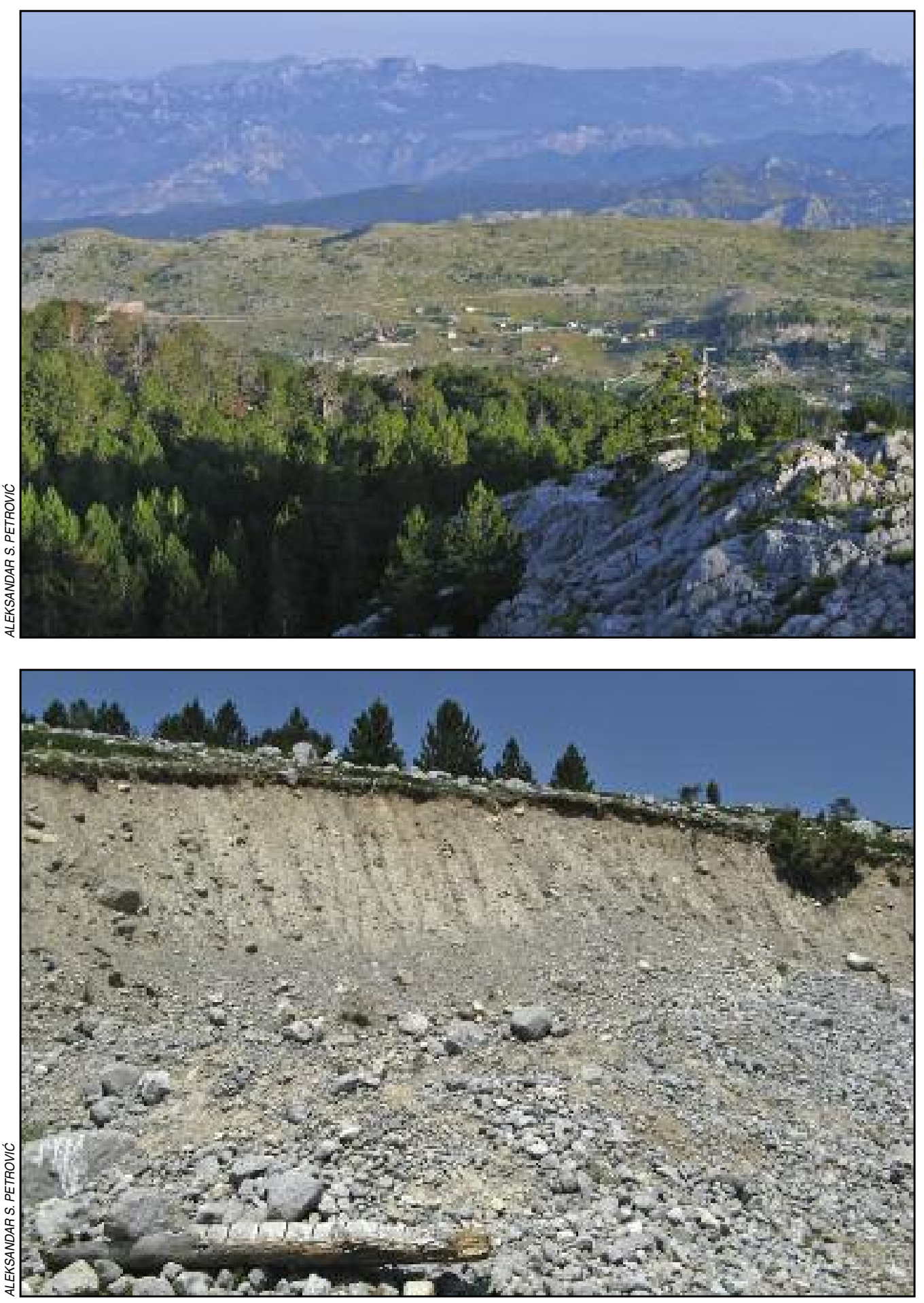

Figure 7: Northern part of the crest at the shepherds' huts in the Kastrat Pasture and the profile through the terminal moraine in the Kastrat Pasture. 


\section{Reconstruction of the Pleistocene glaciers}

The distribution of the Kržanja Member moraines over the Kuči Plateau and in the Veruša Valley indicates that during the most intensive phase of glaciation the Žijovo Range was covered by a unique glacial mass. However, the distribution of cirques and nunataks over the range indicates that the thickness of the ice was not enough to cover all of the peaks. Generally, there were several interconnected glaciers that covered an area of $180 \mathrm{~km}^{2}$.

In the central, northern, and northwestern part of the range a typical ice cap did not develop, but instead a transection glacier. The characteristic of this type of glacier is that climate conditions for its development are such that they allow the existence of an ice cap but, due to the dissection of relief, it does not appear in that form (Benn \& Evans 1998). The existence of fluvial morphology in preglacial relief allows the formation of a system of valley glaciers that divergently spread from the center of the range and separate into one or more glaciers. Moving through the preglacial river valleys, the glaciers moved far from the central parts of the range. The Širokar Glacier was $10 \mathrm{~km}$ long and it extended from Mount Širokar $(1,800 \mathrm{~m})$ to Mount Suvo Polje (1,200 m). Glacial sediments near the village of Brskut indicate that the Bukumir Glacier descended to $1,050 \mathrm{~m}$ and that it was as long as the Širokar Glacier. A similar thing happened to a glacier that descended fromPlateau Momunjevo $(1,750 \mathrm{~m})$. The glacier moved towards the Brskut Valley and after $6 \mathrm{~km}$ it fell over a $300 \mathrm{~m}$ escarpment, after which it merged with the Bukumir Glacier. The Guzovalja Glacier formed in the central part of the range. The summits over 2,000 m (mounts Surdup, Smojan, and Ždrebarnik) were in the background of the source part of the glacier. After $3.5 \mathrm{~km}$ it reached the escarpment above the Brskut Valley (the shepherds' huts in the Bljuštur Pasture), over which it descended and merged with part of the Žijovo Glacier. This unique glacier moved $3.5 \mathrm{~km}$ further through the Velji Do Uvala and to an elevation of $1,100 \mathrm{~m}$.

The glaciers that were formed in the westward-oriented cirques were not very long because after the cirques they immediately flowed over the karst Kržanja-Orahovo Plateau. Their length, together with the length of glacier in the cirques, was between 3 and $6 \mathrm{~km}$. They were formed in larger cirques, below summits that exceed $2,000 \mathrm{~m}$. Due to the considerable power of these glaciers, a significant quantity of glacial sediment was moved and accumulated on the plateau.

The eastern part of the Žijovo Range was under a unique ice cover that mostly resembled an icefield glacier, above which only the Krisitor Cirque protruded in the form of a nunatak (Figure 3). It differs from an ice cap in that it did not have a domelike surface and its flow was influenced by the underlying topography. The central arch of the eastern part of the range forced the ice to move in three directions: towards the Skrobotuša Valley to the north, towards the Cijevna Valley to the east, and towards the Korita Kučka Plateau to the south. The Rikavac Glacier moved farthest, moving towards the north, passing the threshold from the threshold Škala to Mount Rikavac $(1,420 \mathrm{~m})$, and descending through the Skrobotuša Valley as a valley glacier. According to Cvijić (1913), it was one of the source branches of the Vrmuški Glacier. The Krisitor Glacier fell immediately from its cirque down the steep sides of the Cijevna Canyon. The Kunora Glacier moved to the south; part of it ended in the Cijevna Valley and the other, larger, part ended on the Korita Kučka Plateau (1,360 m) and even lower to the southwest, above the village of Orahovo $(1,300 \mathrm{~m})$.

\section{Discussion}

\subsection{Type and volume of glacial maximum}

During the glacial maximum there was a transection glacier in the central, northern, and northwestern part of the range. The Kuči Plateau, especially in the east, southeast, and south, was occupied by an icefield glacier. The glaciers were interconnected over a delevelled saddle on the ridges.

All morphological evidence refers to high-volume glaciations in the range. The main question regarding the glaciation volume is how such a large ice cover formed. Flint's model (1971) of high mountain glaciation formed in the direction of the main flow of air mass can explain the large quantity of snow and ice that accumulated in the Žijovo Range. This model is composed of four phases. In the first phase, the wind brings a maritime humid air mass that produces precipitation as snowstorms that fall over high 
mountain summits, thereby forming an ice cover. For this phase in the development of glaciation, it is necessary to consider the maritime influence of the air mass in the Žijovo Range. The mountains in the Prokletije group are not coastal mountains, but they are broadly open to the Adriatic Sea via the Bojana Valley. The Zijovo Range is the first set of high mountains that the air mass meets, moving along the Bojana Valley and over Lake Skadar. It should also be considered that, during the most intensive phase of glaciation, the Adriatic Sea was smaller and that considerable quantities of water only lay in its southern part, in the Otranto Basin (Correggiari et al. 1996). The circulation in the atmosphere during the last glaciation was different from today. Cyclones that formed in the Bay of Genoa moved over the Adriatic Sea towards the Dinaric Mountains (Kuhlemann et al. 2009). They brought surplus precipitation to the coastal mountains of Montenegro. The cause of the ice cap on Mount Orjen, a mountain at the same latitude as the Žijovo Range, is the fact that lee-side vortices generated moisture-bearing depressions above the Otranto Basin (Hughes et al. 2010). Although these moisture-bearing depressions were weak, they still brought a considerable amount of precipitation to Mount Orjen and the adjacent mountains, including the Žijovo Range.

In the second phase of glaciation development, according to Flint's model, an ice field forms faster on the sides that receive more precipitation and it spreads towards the lower parts of the mountain. This can explain the considerable quantity of glacial mass in the eastern and southeastern parts of the Žijovo Range. Further development of glaciation causes the formation of a unique ice cover over the entire mountain. Eventually, warmer temperatures cause glaciers to melt and retreat to mountain summits.

The volume of glacial maximum is established based on the lowermost limit of glacial deposits. They are located in the Veruša and Brskut valleys and on the Kuči Plateau. Their distribution indicates the influence of preglacial relief and the vicinity of large canyon valleys on the volume of glaciation. These canyon valleys were formed by the action of rivers with a glacio-nival regime (Djurović \& Petrović 2007). The glaciers from the Žijovo Range moved farthest along the Skrobotuša, Veruša, and Brskut valleys. The Kuči Plateau had the opposite influence; that is, its gentler slopes slowed down the advance of glaciers. Part of the glacial mass, together with moraine material, descended from the Žijovo Range and surrounding plateaus directly into river canyons and melted there. Therefore, the quantity of the glacial deposit on the mountain lessened as well as the power of glacier, which continued to move along the Kuči Plateau.

\subsection{Equilibrium line altitude during the glacial maximum}

The reconstruction of the ELA during the glacial maximum was defined by the lowest glacial sediments on the mountain; that is, by the Kržanja Member moraine crest. The THAR method was used to establish the ELA for each of the moraine crests.

The terminal moraines of the Širokar Glacier in the Veruša Valley $(1,240 \mathrm{~m})$, the Bukumir Glacier in the Brskut valley $(1,100 \mathrm{~m})$, and the Radan and Kunora glaciers on the Kržanja-Orahovo Plateau (1,150 m) were studied. These moraines indicate the size of glaciers during the glacial maximum. The average ELA for that glaciation is $1,500 \mathrm{~m}$ (Table 1 ).

Table 1: ELA during the glacial maximum calculated with the THAR method.

\begin{tabular}{lccc}
\hline Glacier & At $(\mathrm{m})$ & Ah $(\mathrm{m})$ & ELA (m) \\
\hline Širokar Glacier & 1,240 & 1,900 & 1,504 \\
Bukumir Glacier & 1,100 & 2,100 & 1,500 \\
Radan and Kunora glaciers & 1,150 & 1,950 & 1,470 \\
\hline
\end{tabular}

The ELA obtained for the Žijovo Range is rather lower than the ELA on Mount Komovi (1,700 m) during the most intensive phase of glaciation (Milivojević 2004) and the ELA of the central part of the Prokletije Mountains in Albania (1,750 m; Milivojević et al. 2008). The ELA of 1,900 m for Mount Šar (Kuhlemann et al. 2009) is higher due to greater distance of the mountain from the Adriatic Sea and high barrier for humid air in the form of the Prokletije Mountains. For the Durmitor Massif, the height of the ELA is at an elevation of approximately 1,540 $\mathrm{m}$ (Djurović 2009), which corresponds to the values obtained for the Žijovo Range. 


\section{Conclusion}

During the Pleistocene, the Žijovo Range and the Kuči Plateau surrounding it were under the influence of a glacial process. This is clearly indicated by traces in the current relief, which are well preserved because of the favorable geological structure of the mountain. The Žijovo Range has erosive and accumulative paleo-features created by a glacial process, among which cirques and moraines dominate.

Geo-morphological mapping of paleoglacial features was used to reconstruct the volume and types of glaciation. Spatial distribution of cirques, waves, nunataks, and moraine crests in the range indicate the existence of a transection glacier during the glacial maximum. Preglacial river valleys allowed the glacier to drain toward the north and northwest. In other directions, the glacier flowed across the Kuči Plateau. The unique glacier on Mount Žijovo covered an area of $180 \mathrm{~km}^{2}$.

Glacial sediments were also found in the Žijovo Range that correspond to different phases of glaciation. The lowest moraine crests in the Kržanja Member correspond to the glacial maximum. They are well preserved on the Kuči Plateau and in the Veruša Valley. Based on these, the ELA for the glacial maximum was established at $1,500 \mathrm{~m}$.

Establishing the age of glacial and fluvio-glacial sediments in the Žijovo Range with the application of appropriate dating methods in future would offer better insight into glacial history. This would take the research on the Žijovo Range into the third, advanced phase in the Hughes et al. (2006) classification: understanding geochronology using radiometric dating and detailed sedimentological analyses.

\section{Acknowledgments}

The author is grateful to the reviewers for very helpful suggestions and comments that led to improvement of this paper. Special thanks to Predrag Djurović and Milovan Milivojević for useful advice and assistance in the field research. Part of this work is included in project no. 177023, financed by the Ministry of Education, Science, and Technological Development of Serbia.

\section{References}

Benn, D. I., Evans, D. J. A. 1998: Glaciers and Glaciation. London.

Blott, S. J., Pye, K. 2001: Gradistat: A grain size distribution and statistics package for the analysis of unconsolidated sediments. Earth surface processes and landforms 26-11. DOI: http://dx.doi.org/10.1002/esp.261

Correggiari, A., Roveri, M., Tricardi, F. 1996: Late Plaistocene and Holocene evolution of the north Adriatic Sea. Il Quaternario 9-2. DOI: http://dx.doi.org/10.1016/0025-3227(79)90130-0

Cvijić, J. 1899: Glacijalne i morfološke studije o planinama Bosne, Hercegovine i Crne Gore. Glas Srpske kraljevske akademije 57.

Cvijić, J. 1903: Novi rezultati o glacijalnoj eposi Balkanskog poluostrva. Glasnik Srpske kraljevske akademije nauka 65.

Cvijić, J. 1913: Ledeno doba u Prokletijama i okolnim planinama. Glas Srpske kraljevske akademije nauka 91.

Djokić, V., Živaljević, M., Petrović, Z. 1968: Tumač za osnovnu geološku kartu Gusinje (1:100,000). Beograd.

Djurović, P. 1996: Visokoplaninski kras Durmitora - geomorfološka studija. Ph. D. thesis. Geografski fakultet Univerziteta u Beogradu. Beograd.

Djurović, P., Petrović, A. S. 2007: Large canyons in Dinaric and Prokletije mountain regions of Montenegro. Geographica Pannonica 11.

Djurović, P. 2009: Reconstruction of Pleistocene glaciers of Mount Durmitor in Montenegro. Acta Geographica Slovenica 49-2. DOI: http://dx.doi.org/10.3986/AGS49202

Djurović, P., Petrović, A. S., Simić, S. 2010: The overall impact of Pleistocene glaciation on morphological diversity of uvalas at Durmitor and Žijovo. Glasnik Srpskog geografskog društva 90-1. DOI: http://dx.doi.org/ 10.2298/GSGD1001017D

Flint, R. F. 1971: Glacial and Quaternary geology. New York.

Hassert, K. 1901: Gletscherspuren in Montenegro. Vortrag gehalten auf dem XIII. Deutschen Geographentag, Brelau. 
Hubbard, B., Glasser, N. 2005: Field technique in glaciology and glacial geomorphology. Chichester.

Hughes, P. D., Gibbard, P. L., Woodward, J. C. 2005: Quaternary glacial records in mountain regions: A formal stratigraphical approach. Episodes 28-2.

Hughes, P. D., Woodward, J. C., Gibbard, P. L. 2006: Quaternary glacial history of the Mediterranean mountains. Progress in physical geography 30. DOI: http://dx.doi.org/10.1191/0309133306pp481ra

Hughes, P. D., Gibbard, P. L., Woodward, J. C. 2007: Geological controls on Pleistocene glaciations and cirque form in Greece. Geomorphology 88. DOI: http://dx.doi.org/10.1016/j.geomorph.2006.11.008

Hughes, P. D., Woodward, J. C., van Calsteren, P. C., Thomas, L. E., Adamson, L. E. 2010: Pleistocene ice caps on the coastal mountains of the Adriatic Sea. Quaternary science reviews 29. DOI: http://dx.doi.org/ 101.1016/j.quascirev.2010.06.032

Kuhlemann, J., Milivojević, M., Krumrei, I., Kubik, P. W. 2009: Last glaciations of Šara range (Balkan peninsula): increasing dryness from the LGM to the Holocene. Austrian journal of Earth science 102.

Martelli, A. 1908: Studio geologico sul Montenegro sud-orientale e littoraneo. Memorie della R. Accademia dei Lincei., Classe di scienze fisiche, matematiche e naturali 6.

Meierding, T. C. 1982: Late pleistocene glacial equilibrium-line altitudes in the Colorado Front Range: A comparison of methods. Quaternary research 18-3. DOI: http://dx.doi.org/10.1016/0033-5894(82)90076-X

Milivojević, M. 2004: Glacijalna morfologija Komova. Glasnik Srpskog Geografskog Društva 84-2.

Milivojević, M., Menković, Lj., Calić, J. 2008: Pleistocene glacial relief of the central part of Mt. Prokletije (Albanian Alps). Quaternary international 190. DOI: http://dx.doi.org/10.1016/j.quaint.2008.04.006

Petrović, A. S. 2007: Pleistocena glacijacija gornjeg toka Veruše. Zbornik radova Geografskog fakulteta Univerziteta u Beogradu 55.

Petrović, A. S. 2009: Pleistoceni glacijalni reljef Žijova. M. Sc. thesis, Univerziteta u Beogradu, Geografski fakultet, Beograd.

Porter, S. C. 2001: Snowline depression in the tropics during the last glaciation. Quaternary science reviews 20-10. DOI: http://dx.doi.org/10.1016/S0277-3791(00)00178-5

Stepišnik, U., Ferk, M., Kodelja, B., Medenjak, G., Mihevc, A., Natek, K., Žebre, M. 2010: Glaciokras of western Orjen, Montenegro. Cave and karst science 36-1.

Stepišnik, U. and Žebre, M. 2011: Glaciokras Lovčena. E-GeograFF 2. Ljubljana.

Vinassa de Regny, P. 1901: Tracce glaciali net Montenegro. Reale accademia del Lincei 10. Roma.

Vojnogeografski institut, 1982. Orto-foto snimci Žijova 1:50,000. Beograd.

Živaljević, M., Đokić, V., Pajović, M. 1967: Tumač za osnovnu geološku kartu Titograd (1:100,000). Beograd. 